\title{
Is There a Random Walk in Indian Foreign Exchange Market?
}

\author{
Alpana Vats (Corresponding Author) \\ Economist, Andhra Bank, Head Office, Saifabad \\ Hyderabad, Andhra Pradesh, India, PIN 500004 \\ Tel: 040-2332-0239Ｅ-mail: vats.alpana@gmail.com \\ Prof. B. Kamaiah \\ Dept. of Economics, University of Hyderabad \\ Gachibowli, Hyderabad, Andhra Pradesh, India, PIN 500046
}

\author{
Received: July 7, 2011 \\ Accepted: July 18, 2011 \\ Published: November 1, 2011 \\ doi:10.5539/ijef.v3n6p157 \\ URL: http://dx.doi.org/10.5539/ijef.v3n6p157
}

The views expressed in the paper are those of authors and do not represent of those of institutions which they belong. Errors and omissions, if any, are the sole responsibility of the authors.

\begin{abstract}
The study utilizes both parametric and non parametric tests to examine the behavior of weekly return of eight currencies relative to Indian Rupee in post liberalization period. Also, bootstrap resampling technique is used to calculate the significance levels of variance ratio statistics. The results show strong evidence of rejection of random walk for US Dollar and Hong Kong Dollar relative to Indian Rupee. Further, there is mixed evidence of random walk for Singapore Dollar. However, for other five currencies random walk could not be rejected. Overall, there is evidence against weak form efficient foreign exchange market in India.
\end{abstract}

Keywords: Random walk hypothesis, Exchange rates, Indian forex market, Variance ratio test

\section{Introduction}

In last two decades Indian foreign exchange market has transformed from a tightly controlled market of fixed exchange rate system to market driven managed float system. The year 1993 marked a new beginning in the foreign exchange market of India when Indian Rupee was allowed to be determined primarily by market forces of demand and supply. Subsequently, regulatory and institutional measures have increased depth, liquidity and efficiency in the foreign exchange market. The constant changes and rapid innovation in trading methods and products have lead to increase in daily turnover in Indian foreign exchange market which has grown manifold in last few years. The daily average turnover of Indian foreign exchange market has increased from USD 2.45 billion in 1998 to USD 38.36 billion in 2007. However, it has declined to USD 27.36 billion in 2010. In percentage terms, it constitutes $0.54 \%$ of the world foreign exchange market. With the growing integration of Indian economy with the world economy, the Indian Rupee has gained importance in recent years. The liberal and market oriented regime adopted by the India has improved the share of Indian rupee in world's total daily foreign exchange transaction from $0.09 \%$ in 1998 to $0.95 \%$ in 2010 . With the increased turnover and market determined exchange rate system, the issue of foreign exchange market efficiency has assumed importance in India in recent years.

Markets are perceived as efficient when market prices reflect all available information, so that it is not possible for any trader to earn excess profits by predicting price. The price predictability gives traders scope for abnormal profit and at the same time warranting government intervention in the market. Though there exists voluminous literature investigating rate predictability in the foreign exchange market, there are very few studies in Indian context. The present paper attempts to investigate weak form efficiency of Indian foreign exchange market taking weekly exchange rate of eight majorly traded currencies in Indian market during the period from July 1991 to June 2010.

The study has employed both parametric and non-parametric tests to examine the efficiency of Indian foreign exchange market. The parametric tests employed are the Ljung - Box test, Unit root tests, Lo-MacKinlay Variance Ratio and Chow-Denning Multiple Variance Ratio tests. The non-parametric tests include Wight's Rank and Sign (2000) test and Run test. The rest of the paper is divided into five sections including Introduction. The second section reviews some important literature on foreign exchange market efficiency. The third section describes data 
and methodology used in this paper. The empirical results are discussed in the fourth section followed by concluding remarks in the fifth section.

\section{Literature Review}

In this section we attempt a quick review of select important studies in this area. The study by Liu and He (1991) used Lo -MacKinlay variance ratio and Box-Pierce Q tests on five developed market currencies and rejected the random walk hypothesis (RWH) for all currencies. A similar study by Ajayi and Karemera (1996) on South Asian foreign exchange markets rejected RWH but found that rejection were not robust to hetroscedasticity. Wu and Chen (1998) used panel unit root test to examine the stationarity of forward premia and interest rate differentials for nine OECD countries and found evidence in support of the RWH. Lee et al (2001) used Joint Variance Ratio test and technical trading rule to examine the price predictability of nine Asian currencies and found little evidence of correlations in exchange rate except the Korean won. Also, technical analysis showed significant profit for Korean Won, Singapore Dollar and Taiwan Dollar.

Chang (2004) used variance ratio bootstrapped resampling technique on five developed market currencies and supported RWH for all currencies except for Japanese yen. Franch and Opong (2005a) used Lo-MacKinlay variance ratio test and Wright's (2000) ranks and signs test to examine random walk in Euro exchange rate against ten currencies and rejected random walk for Canadian Dollar, Singapore Dollar, Newzeland Dollar, Swiss Franc and Norway Kroner. A similar study by Lima and Tabak (2007) supported RWH for emerging market currencies. Chow Denning Multiple Variance Ratio test employed on 10 Pasific Basin economies by Shyh-Wei-Chen (2009) rejected RWH for pacific basin foreign exchange market. A study by Lima and Tabak (2009) using VR, Multiple VR, technical trading rule refuted RWH for Brazilian exchange rate for long investment horizon but found it consistent with RWH for short run. Most of these studies are in the context of currencies of developed countries or Pacific Basin countries

Literature on the behavior of Indian Rupee (INR) has been scanty. Kohli (2002) examined mean reversion using four versions of real exchange rates for time period from 1993 to 2002 at monthly frequency. Unit root, variance ratio and cointegration tests that were employed in the study supported mean reversion in case of CPI and WPI/CPI deflated series of real exchange rates, but rejected stationarity in 5 currency and 36 currency REER series. Other studies by Pattnaik et. al. (2003), and Moore and Pentecost (2006) applied a bivariate vector autoregressive (VAR) model of the nominal and real exchange rates to examine the main source of variation in real exchanges. Pattnaik et al. (2003) used data for the period from April 1993 to December 2001, whereas Moore and Pentecost (2006) used data for the period between March 1993 and January 2004. Both the studies have concluded that real shocks were the main sources of the fluctuations in both nominal and real exchange rates for India. A similar study by Inoue and Hamori (2009), using structural VAR, with three variables i.e. nominal exchange rate, real exchange rate and relative output of India and US/Euro Area from 1999 to 2009, concluded that real shocks were the main drives of the fluctuations in real and nominal exchange rates. Since these studies are silent about predictability of Indian rupee, this study attempts to investigate exchange rate predictability and weak form informational efficiency of Indian foreign exchange market in post liberalization period using both parametric and non parametric tests.

\section{Data and Methodology}

\subsection{Data}

To investigate the efficiency in Indian market in post liberalization period, this study has used weekly (Wednesday) nominal exchange rate of Indian Rupee expressed as per unit of eight foreign currencies namely, Pound sterling (GBP), US Dollar (USD), Swiss Franc (CHF), Australian Dollar (AUD), Newzeland Dollar (NZD), Japanese Yen (JPY), Singapore Dollar (SGD) and Hong Kong Dollar (HKD) against INR from July 1991 to June 2010. The weekly return is calculated as the first log difference of the exchange rate on Wednesday closing. The data is obtained from Bloomberg data base.

\subsection{Methodology}

In an informationally efficient market, prices fully reflect all available and relevant information, meaning an absence of excess-profit opportunities. Of the different forms of efficiency, this study will investigate the weak form market efficiency, in which asset price reflects all published information. Price changes in weak form efficient markets are independent and fluctuate only in response to the random flow of news. Future price of an asset is not related to its past price which is described as random walk process. To test the weak form of market efficiency many parametric and non parametric tests are used. This study will use the following widely used parametric and non parametric tests.

\subsubsection{LB Q-Test}

Ljung-Box Q-statistic(1978) is a variant of Box-Pierce Q statistic (1970) used to test the joint hypothesis that all the 
autocorrelation coefficients upto lag $\mathrm{m}$ are simultaneously equal to zero. Ljung -Box Q-statistic is defined as:

$Q=n(n+2) \sum_{k=1}^{m}\left(\frac{\rho_{k}^{2}}{n-k}\right)$

Where $\mathrm{n}$ is number of observations, $\mathrm{m}$ is number of lags, and $\rho_{\mathrm{k}}$ is autocorrelation coefficient at lag $\mathrm{k}$. $\mathrm{Q}$ follows the chi-square distribution with $\mathrm{m}$ degrees of freedom.

\subsubsection{Unit Root Test}

First, the two well known unit root tests namely Augmented Dicky Fuller (ADF) and Phillip- Perron (PP, 1988) tests are used to examine unit root in the series. We apply these two tests on exchange rates as well as on exchange rate returns and expect the exchange rate to be $\mathrm{I}(1)$ and the returns series to be $\mathrm{I}(0)$. Next, the Kwiatkowski-Phillips-Schmidt-Shin (KPSS, 1992) test is used to investigate the stationarity in the series. In contrast to ADF and PP, the null hypothesis of KPSS test is that the series is stationary.

\subsubsection{Variance Ratio Test}

This is the most widely used econometric tool since the pioneering work of Lo and MacKinlay( 1988). If a time series of returns follows a random walk then in a finite sample, the increments in the variance are linear in the observation interval, i.e., the variance of returns should be proportional to the sample interval. Thus, the variance of monthly returns should be four times the variance of weekly returns. In order to test the RWH, we use the VR defined as:

$V R(k)=\frac{\hat{\sigma}^{2}\left(r_{t}^{k}\right) / k}{\hat{\sigma}^{2}\left(r_{t}\right)}=1$

where $r_{t}^{k}=p_{t}-p_{t-k}$.

The hypothesis to test random walk against non-random walk is equivalent to testing $\operatorname{VR}(k)=1$ against $\operatorname{VR}(k) \neq 1$.

Lo and MacKinlay suggested the test statistics $\mathrm{M}_{1}(\mathrm{k})$, given by:

$M_{1}(k)=\frac{V R(k)-1}{\sqrt{\frac{2(2 k-1)(k-1)}{3 k T}}}$

which follows standardised normal distribution. Lo and MacKinlay also suggested statistic, $\mathrm{M}_{2}(\mathrm{k})$ that is robust to heteroscedasticity and have non-normal disturbances. Lo and MacKinlay (1989) further show that the variance ratio test is more reliable than the Box-Pierce Q-test which is traditionally used for detecting serial correlation.

3.2.4 Chow and Denning (1993) Multiple Variance Ratio Test

Chow and Denning (1993) stressed that the sequential procedure of Lo and MacKinlay (1988) leads to an oversized testing strategy and also it ignores the joint nature of testing for the RWH. Chow and Denning (1993) have shown that to test for multivariate VR it is important to control for the joint size test statistic. They provide a procedure for the multiple comparison of the set of variance estimates. For the set of ' $m$ ' test statistics, the random walk hypothesis is rejected if any one of the estimated variance ratios is significantly different from one. Hence only the maximum absolute value in the set of test statistics is considered.

$$
C D=\max _{1 \leq k \leq m}\left|M_{1}(k)\right|
$$

The authors show that the multivariate test statistic has a Studentized Maximum Modulus distribution with ' $\mathrm{m}$ ' parameters and ' $\mathrm{T}$ ' degrees of freedom, equal to the sample size.

\subsubsection{Kim's (2006) Bootstrapped Variance Ratio Test}

The conventional VR tests, such as the Lo-MacKinlay test and Chow Denning, are asymptotic tests in that their sampling distributions are approximated by their limiting distributions. In general, the ability of the asymptotic distribution to approximate the finite-sample distribution depends crucially on the value of the horizon $\mathrm{k}$. More specifically, rather than being normally distributed (when standardized by $\mathrm{T}$ ) as the theory states, the statistics are severely biased and right skewed for large k (relative to T) (Lo and MacKinlay, 1989), which makes application of the statistic problematic.

As an alternative, some researchers proposed to employ a bootstrap method, which is a resampling method that approximates the sampling distribution of a test statistic (Efron, 1979) to the VR test statistic. Kim (2006) suggested a wild bootstrap that is a resampling method that approximates the sampling distribution of the VR statistic, and is applicable to data with unknown forms of conditional and unconditional heteroscedasticity. It is applied to the wild 
bootstrap to Lo Lackinly and Chow Denning's heteroscedastic robust version.

\subsubsection{Wright's Rank and Sign VR tests}

Wright's (2000) tests have two advantages over the Lo-MacKinlay test when sample size is relatively small: (i) as the rank (R 1 and R 2) and sign (S 1 and S 2) tests have an exact sampling distribution, there is no need to resort to asymptotic distribution approximation, and (ii) the tests may be more powerful than the conventional VR tests against a wide range of models displaying serial correlation, including fractionally integrated alternatives. The tests based on ranks are exact under the i.i.d. assumption, whereas the tests based on signs are exact even under conditional heteroscedasticity. Moreover, Wright (2000) showed that ranks-based tests display low-size distortions, under conditional heteroscedasticity. Wright's (2000) $\mathrm{S}_{2}$ test is not considered in this study as Monte Carlo simulation results clearly indicate that its size and power properties are quite inferior to those of $\mathrm{S}_{1}$.

\subsubsection{Joint Wright Test}

Belaire-Franch and Contreras (2004) proposed to substitute the standard VR tests by Wright's rank and sign based tests in the definition of the Chow and Denning (1993) procedure to create multiple rank and sign VR tests. The ranks based procedures are exact under the i.i.d. assumption whereas the sign based procedures are exact under both i.i.d and martingale difference sequence assumptions.

\subsubsection{Run Test}

The paper uses the Wald-Wolfowitz (1940) Run test for the randomness of the series. Run testing is a strong test for randomness in investigating serial dependence in asset price movements and compares the expected number of runs from a random process with the observed number of runs. The test is non-parametric and is independent of the normality and constant variance of data. A run is defined as a series of identical signs that are preceded or are followed by a different sign or no sign at all. That is, given a sequence of observations, the runs test examines whether the value of one observation influences the values taken by later observations. If there is no influence (the observations are independent), the sequence is considered random. It is assumed that the sample proportion of positive, negative and zero price changes are good estimates of the population's proportions. Runs test shows the cutting point, the number of runs, the number of cases below the cutting point, the number of cases greater than or equal to the cutting point, and the test statistics $\mathrm{Z}$ with its observed significance level. The total number of runs is a measure of randomness, since too many or too few runs suggest dependence between observations.

\section{Empirical Results}

Table 1 reports the descriptive statistics of exchange rate weekly return against Indian Rupee (INR). The mean of the weekly return indicates the presence of non zero return on holding foreign exchange. JPY and CHF have the highest mean return followed by SGD and NZD. GBP gives the lowest return followed by HKD. Also, JPY and CHF with highest standard deviation are the most volatile among the eight currencies. It can be observed that the skewness of NZD is very close to zero. Returns of all other currencies except AUD are positively skewed. This indicates that AUD has tendency to depreciate. As expected, all the exchange returns are highly leptokurtic, indicating distribution with fat tail and more extreme movements in exchange rates than one would expect under the assumption of normal distribution. Additionally, Jarque Bera test also indicates that the returns of all currencies are not normally distributed. The result of ARCH LM test in the table suggest that all exchange rates show strong conditional hetertoscedasticity.

\subsection{Results}

To start with, unit root tests have been conducted. Tables 2 and 3 exhibit the results of unit root tests namely, ADF, PP and KPSS at level and at log first difference, respectively. Lag length for ADF test is selected based on general to specific approach, setting maximum number of lags equal to twenty and using $10 \%$ critical value to determine the significance level of the t-statistics on the last lag. The ADF test has rejected the null of unit root to support the alternative of stationarity for USD, SGD and HKD at $10 \%$ significance level for the drift model. The PP test has rejected the null of unit root in six currencies i.e. GBP, USD, CHF, JPY, SGD and HKD at 5 percent or lower significance level for the model with drift. However, KPSS test which has null of stationarity against alternative of unit root has rejected the null for all currencies at $1 \%$ significance level. For the model with both drift and trend, ADF test has supported stationary in AUD and SGD. However, PP has supported stationarity in all currencies except GBP. KPSS test has rejected stationarity in all currencies.

If a series shows a random walk, then its first difference is expected to be stationary. ADF and PP unit root tests have supported stationarity in log first difference series of all the currencies for both drift and trend model at one \% significance level. However, the KPSS test suggests stationarity in 4 currencies except GBP, USD, SGD and HKD for drift model and stationarity in six currencies except JPY and SGD in trend model. The other condition for a 
time series to depict random walk is that its increments have to be serially uncorrelated. The Ljung Box test suggests autocorrelation in USD and HKD returns series at 1\% significance level for lag 15 (table 1).

Next we have applied variance ratio test to examine autocorrelation in return series which is considered to have more power than the above tests. The conventional Lo - MacKinlay variance ratio test used at lag length of 2, 4, 8 and 16 tests the null of variance ratio equal to 1 .

Table 4 shows that Variance Ratio is more than 1 for USD and HKD and less than one for AUD and NZD for all lags. The test statistics under maintained hypothesis of homoscedasticity, indicated as $\mathrm{M}_{1}(\mathrm{k})$, are given in second row and under hypothesis of heteroscedasticity, indicated as $\mathrm{M}_{2}(\mathrm{k})$, are given in third row of the cell. Under homoscedasticity, the null of Variance Ratio equals unity is rejected by GBP, USD, SGD and HKD at minimum $10 \%$ significance level. The rejection of null under the maintained hypothesis of homoscedasticity may be either due to the presence of heteroscedasticity or serial correlation in the data series. If the rejection of null is robust to heteroscedasticity, then the rejection is due to the existence of serial correlation in the data series. Since there is evidence of ARCH effect in the series we have employed hetroscedasticity robust variance ratio test. The $\mathrm{M}_{2}(\mathrm{k})$ statistics which is robust to hetroscedasticity support random walk for all currencies. The Chow Denning Multiple Variance Ratio test also supports the findings of Lo and MacKinlay Variance Ratio test, rejecting unity of variance ratio for USD and HKD at $1 \%$ significance. Similar to hetroscedasticity robust Lo MacKinlay test, heteroscedasticity robust Chow Denning statistic supports the null of random walk in all currencies. Also, the variance ratio of more than unity indicates presence of positive serial correlation or exchange rate undershooting phenomena and official intervention in Indian foreign exchange market.

As discussed earlier, Lo -MacKinlay and Chow Denning variance ratio tests are asymptotic tests and their sampling distributions are approximated by their limiting distributions and hence the test statistics are biased and right skewed. To overcome this, as suggested by Kim (2006), bootstrapped Lo-MacKinlay and Chow Denning hetroscedastic robust version tests are employed. The p-value of the tests are shown in table 5. The bootstrapped Lo-MacKinlay test has rejected null of unit variance ratio for USD and HKD at 10\% significance level and bootstrapped Chow Denning test has rejected the null only for HKD at $10 \%$ significance level.

Next, Wright's (2000) rank and sign, a non parametric test, is employed to examine RWH in Indian forex market. Results of the test are presented in table 6. Following the rule of thumb: "reject null if there are more than two rejections at any levels of significance", RWH is rejected for USD, SGD and HKD at at least $10 \%$ significance level. However, SGD shows weaker evidence against RWH than those of USD and HKD. It rejects random walk based on $\mathrm{R} 2$ only for $\mathrm{k}=4$ at 10 percent significance level. It is to be noted that all test statistics (R1, R2 and S1) give fairly consistent inference. Though AUD too has rejected the null, we have not considered it as the rejection is only at $\mathrm{k}=16$ by $\mathrm{S} 1$, which is a weak test compared to $\mathrm{R} 1$ and $\mathrm{R} 2$. The joint Wright multiple variance ratio test proposed by Belaire-Franch and Contreras (2004) supports the result of Wright (2000) rank and sign test and rejects RWH for USD, SGD and HKD.

Further non parametric run test is also employed to investigate randomness in the series. Table 7 provides results of the test under the null hypothesis of return independence or weak form efficiency for the eight currencies. The negative Z- statistics of USD, AUD, JPY, SGD and HKD indicate that the actual number of runs falls short of the expected number of return and there is serial dependence in the rate movement. However, the result is highly significant only for USD and HKD at $1 \%$ and rejects RWH for these two currencies.

\section{Concluding Remarks}

This paper employed both parametric and non parametric tests to examine the efficiency in Indian foreign exchange market during the period, July 1991 to June 2010. All the tests have given fairly consistent results. They strongly suggest randomness in GBP, CHF, AUD, NZD and JPY in Indian market. SGD has shown mixed result. However, for two currencies i.e. USD and HKD all tests by and large have rejected Random Walk, suggesting predictability for these two currencies with respect to INR. Also, for these two currencies variance ratio is more than one suggesting positive serial correlations or exchange rate undershooting phenomena and official intervention in Indian foreign exchange market. Rejection of random walk in foreign exchange rates carries implications for exchange rate forecasting, currency futures and option pricing and investors' international portfolio choices.

\section{References}

Ajayi, R. A. Karemera, D. (1996). A variance ratio test of random walks in exchange rates: evidence from Pacific Basin economics. Pacific-Basin Financial Journal. 4 (1), 77-91. http://dx.doi.org/10.1016/0927-538X(95)00022-D

Belaire-Franch, J. Contreras, D. (2004). Ranks and signs-based multiple variance ratio tests. Working Paper, Department of Economic Analysis, University of Valencia. 
Belaire-Franch J. Opong, K. K. (2005a). Some evidence of random walk behavior of Euro exchange rates using ranks and signs. Journal of Banking and Finance. 29(7), 1631-1643. http://dx.doi.org/10.1016/j.jbankfin.2004.06.031

Box, G. E. P. Pierce, D. A. (1970). Distribution of the Autocorrelations in Autoregressive Moving Average Time Series Models. Journal of the American Statistical Association. 65(332), 1509-1526. http://dx.doi.org/10.2307/2284333

Campbell, J.Y. Lo, A.W. \& MacKinlay, A.C. (1997). The Econometrics of Financial Markets, Princeton, NJ: Princeton University Press.

Chang, Y. (2004). A re-examination of variance ratio test of random walks in foreign exchange rates. Applied Financial Economics. 14(9), 671-679, http://dx.doi.org/10.1080/0960310042000233449

Charles, A. Darne, O. (2009). Variance ratio tests of random walk: An overview. Journal of Economic Surveys. 23 (3), 503-527, http://dx.doi.org/10.1111/j.1467-6419.2008.00570.x

Chen, Shyh-wei (2009). Random walks in Asian foreign exchange markets: evidence from new multiple variance ratio tests. Economics Bulletin. 29 (2), 1309-1320.

Chow. K.V. Denning, K. (1993). A simple multiple variance ratio test. Journal of Econometrics. 58(3), 385-401, http://dx.doi.org/10.1016/0304-4076(93)90051-6

Fama, E. (1970). Efficient Capital Markets: A Review of Theory and Empirical Work. The Journal of Finance. 25(2), 383-417, http://dx.doi.org/10.2307/2325486

Inoue T. Hamori, S. (2009). What explains Real and Nominal Exchange Rate Fluctuations?: Evidence from SVAR Analysis for India. Economics Bulletin, 29(4), 2803-15.

Karemera, D. Ojah, K. \& Cole, J.A. (1999). Random walks and market efficiency tests: Evidence from emerging equity markets. Review of Quantitative Finance and Accounting. 13(2), 171-188.

Kim, J. H. (2006). Wild bootstrapping variance ratio tests. Economics Letters. 92(1), 38-43, http://dx.doi.org/10.1016/j.econlet.2006.01.007

Kisaka, S.E. Gituro, W. Ganesh, P.\& Rose, N.W. (2008). An analysis of the efficiency of the foreign exchange market in Kenya. Economics Bulletin. 14 (2), 1-13.

Kohli, R. (2002). Real Exchange Rate Stationarity in Managed Floats Evidence from India. Economic and Political Weekly, February 2, 2002, 475-482.

Kwiatkowski, D. Phillips, P.C.B. Schmidt, P. \& Shin, Y. (1992). Testing the Null Hypothesis of Stationarity against the Alternative of a Unit Root. Journal of Econometrics 54(1-3), 159-178. http://dx.doi.org/10.1016/0304-4076(92)90104-Y

Lee, C. I., M. Pan, S. \& Liu, Y.A. (2001). On market efficiency of Asian foreign exchange rates: evidence from a joint variance ratio test and technical trading rules. Journal of International Financial Market, Institutions and Money. 11(2), 199-214, http://dx.doi.org/10.1016/S1042-4431(00)00050-0

Lima, E. J. A. Tabak, B.M. (2006). Testing for inefficiency in emerging markets exchange rates. Chaos, Solitons and Fractals. 33(2), 617-622, http://dx.doi.org/10.1016/j.chaos.2006.01.043

Ljung, G.M. Box, G.E.P. (1978). On a Measure of a Lack of Fit in Time Series Models. Biometrika. 65, 297-303. http://dx.doi.org/10.1093/biomet/65.2.297

Lo, A. MacKinlay, A.C. (1988). Stock market prices do not follow random walks: Evidence from a simple specification test. Review of Financial Studies. 1(1), 41-66, http://dx.doi.org/10.1093/rfs/1.1.41

Lo, A.W. MacKinlay, A.C. (1989). The size and power of the variance ratio test in finite samples: a Monte Carlo investigation. Journal of Econometrics 40(2) 203-238, http://dx.doi.org/10.1016/0304-4076(89)90083-3

Liu, C.Y. He, J. (1991). A variance-ratio test of random walks in foreign exchange rates. Journal of Finance. 46(2), 773-785, http://dx.doi.org/10.2307/2328848

Moore, T. Pentecost E.J. (2006). The source of real exchange rate fluctuations in India, Indian Economic Review, 41, 9-23.

Ojah, K. Karemera, D. (1999). Random walks and market efficiency tests of Latin American Emerging equity markets: A revisit. The Financial Review. 18(2), 57-72, http://dx.doi.org/10.1111/j.1540-6288.1999.tb00454.x

Pattnaik, P. K. Kapur, M.K. \& Dhal, S.C. (2003). Exchange Rate Policy and Management: The Indian Experience. Economic and Political Weekly. 38(22),2139-2154

Phillips, P. Perron, P. (1988). Testing for a unit root in time series regression. Biometrika. 75(2), 335-346, 
http://dx.doi.org/10.2307/2336182

Said, E. Dickey, David A. (1984). Testing for Unit Roots in Autoregressive Moving Average Models of Unknown Order. Biometrika. 71(3), 599-607, http://dx.doi.org/10.2307/2336570

Stoline, M. R. Ury, H.K. (1979). Tables of the studentized maximum modulus distribution and an application to multiple comparisons among means. Technometrics. 21(1), 87-93, http://dx.doi.org/10.2307/1268584

Tabak, B. M. Lima, E.J.A. (2009). Market efficiency of Brazilian exchange rate: Evidence from variance ratio statistics and technical trading rules. European Journal of Operational Research. 194(3), 874-820, http://dx.doi.org/10.1016/j.ejor.2008.01.005

Urrutia, J.L. (1995). Tests of random walk and market efficiency for Latin American emerging markets. Journal of Financial Research. 18(3), 299-309.

Wald, A. Wolfowitz,J. (1940). On a test whether two samples are from the same population. The Annals of Mathematical Statistics. 11(2), 147-162, http://dx.doi.org/10.1214/aoms/1177731909

Wright, J. (2000). Alternative variance-ratio tests using ranks and signs. Journal of Business and Economics Statistics. 18(1), 1-9, http://dx.doi.org/10.2307/1392131

Wickremsinghe, G.B. (2008). Predictability of Exchange Rates in Sri Lanka; A test of the Efficient Market Hypothesis. Asian Academy of Management Journal of Accounting and Finance. 3(2), 43-59.

$\mathrm{Wu}$, J. Chen, S. (1998). Foreign exchange market efficiency revisited. Journal of International Money and Finance. 12(5), 831-838, http://dx.doi.org/10.1016/S0261-5606(98)00028-X

Table 1. Summary Statistics for weekly return

\begin{tabular}{|c|c|c|c|c|c|c|c|c|c|}
\hline Currencies & Mean & Minimum & Maximum & Std. Dev. & $\begin{array}{l}\text { Skewnes } \\
\text { s }\end{array}$ & Kurtosis & Jarque-Bera & $\begin{array}{l}\text { Ljung Box Q } \\
\text { Statistic (Lag 15) }\end{array}$ & ARCH LM \\
\hline GBP & 0.0302 & -4.0903 & 15.2946 & 0.6479 & 0.1662 & 7.9497 & $\begin{array}{l}2623.39^{\mathrm{a}} \\
(0.0000)\end{array}$ & $\begin{array}{l}9.4454 \\
(0.2222)\end{array}$ & $\begin{array}{l}68.7472^{a} \\
(0.0000)\end{array}$ \\
\hline USD & 0.0347 & -2.0546 & 14.8641 & 0.4035 & 3.2919 & 37.4459 & $\begin{array}{l}59826.97^{\mathrm{a}} \\
(0.0000) \\
\end{array}$ & $\begin{array}{l}40.2191^{\mathrm{a}} \\
(0.0000)\end{array}$ & $\begin{array}{l}51.9104^{\mathrm{a}} \\
(0.0000)\end{array}$ \\
\hline $\mathrm{CHF}$ & 0.0484 & -3.1042 & 15.1343 & 0.7310 & 0.4898 & 3.7520 & $\begin{array}{l}624.01^{\mathrm{a}} \\
(0.0000) \\
\end{array}$ & $\begin{array}{l}7.596 \\
(0.3696) \\
\end{array}$ & $\begin{array}{l}31.1895^{\mathrm{a}} \\
(0.0083)\end{array}$ \\
\hline AUD & 0.0399 & -6.8424 & 15.1253 & 0.7143 & -0.4074 & 12.5921 & $\begin{array}{l}6594.25^{\mathrm{a}} \\
(0.0000) \\
\end{array}$ & $\begin{array}{l}4.3369 \\
(0.7403) \\
\end{array}$ & $\begin{array}{l}51.8881^{\mathrm{a}} \\
(0.0000) \\
\end{array}$ \\
\hline NZD & 0.0429 & -4.0985 & 4.3878 & 0.7100 & -0.0006 & 4.2413 & $\begin{array}{l}746.42^{a} \\
(0.0000) \\
\end{array}$ & $\begin{array}{l}5.436 \\
(0.6069) \\
\end{array}$ & $\begin{array}{l}74.5542^{\mathrm{a}} \\
(0.0000) \\
\end{array}$ \\
\hline JPY & 0.0527 & -2.8821 & 5.1763 & 0.7484 & 1.1056 & 6.4286 & $\begin{array}{l}1915.24^{\mathrm{a}} \\
(0.0000)\end{array}$ & $\begin{array}{l}4.6036 \\
(0.7082) \\
\end{array}$ & $\begin{array}{l}71.564^{\mathrm{a}} \\
(0.0000) \\
\end{array}$ \\
\hline SGD & 0.0451 & -2.5964 & 15.1473 & 0.4576 & 2.2070 & 25.7144 & $\begin{array}{l}28176.90^{\mathrm{a}} \\
(0.0000) \\
\end{array}$ & $\begin{array}{l}7.396 \\
(0.3888) \\
\end{array}$ & $\begin{array}{l}71.6472^{a} \\
(0.0000) \\
\end{array}$ \\
\hline HKD & 0.0344 & -2.0313 & 14.9172 & 0.4023 & 3.3328 & 37.7593 & $\begin{array}{l}34056.32^{\mathrm{a}} \\
(0.0000)\end{array}$ & $\begin{array}{l}40.601^{\mathrm{a}} \\
(0.0000)\end{array}$ & $\begin{array}{l}51.3369^{\mathrm{a}} \\
(0.0000)\end{array}$ \\
\hline
\end{tabular}

${ }^{\mathrm{a}}$ and ${ }^{\mathrm{b}}$ denote statistical significance at $1 \%$ and $5 \%$ levels, respectively.

Table 2. Results of Unit Root test for log level

\begin{tabular}{|l|l|l|l|l|l|l|}
\hline & \multicolumn{2}{|c|}{ ADF } & \multicolumn{2}{c|}{ PP } & \multicolumn{2}{c|}{ KPSS } \\
\hline CURRENCIES & \multicolumn{1}{|c|}{ Drift } & \multicolumn{1}{c|}{ Trend } & \multicolumn{1}{c|}{ Drift } & \multicolumn{1}{c|}{ Trend } & \multicolumn{1}{c|}{ Drift } & \multicolumn{1}{c|}{ Trend } \\
\hline GBP & -1.8203 & -1.430 & $-3.207^{\mathrm{a}}$ & -3.051 & $17.238^{\mathrm{a}}$ & $2.831^{\mathrm{a}}$ \\
\hline USD & $-2.6213^{\mathrm{c}}$ & -1.854 & $-4.040^{\mathrm{a}}$ & $-3.486^{\mathrm{b}}$ & $14.825^{\mathrm{a}}$ & $4.095^{\mathrm{a}}$ \\
\hline CHF & -1.857 & -2.959 & $-3.104^{\mathrm{b}}$ & $-4.909^{\mathrm{a}}$ & $16.913^{\mathrm{a}}$ & $0.754^{\mathrm{a}}$ \\
\hline AUD & -2.166 & $-4.051^{\mathrm{a}}$ & -2.176 & $-4.166^{\mathrm{a}}$ & $16.679^{\mathrm{a}}$ & $1.029^{\mathrm{a}}$ \\
\hline NZD & -1.812 & -2.406 & -2.479 & $-3.141^{\mathrm{c}}$ & $15.332^{\mathrm{a}}$ & $1.093^{\mathrm{a}}$ \\
\hline JPY & -2.455 & -3.098 & $-3.654^{\mathrm{a}}$ & $-4.240^{\mathrm{a}}$ & $13.211^{\mathrm{a}}$ & $1.606^{\mathrm{a}}$ \\
\hline SGD & $-2.647^{\mathrm{c}}$ & $-3.161^{\mathrm{c}}$ & $-4.713^{\mathrm{a}}$ & $-6.031^{\mathrm{a}}$ & $15.299^{\mathrm{a}}$ & $2.494^{\mathrm{a}}$ \\
\hline HKD & $-2.625^{\mathrm{c}}$ & -1.903 & $-4.066^{\mathrm{a}}$ & $-3.525^{\mathrm{b}}$ & $14.741^{\mathrm{a}}$ & $4.052^{\mathrm{a}}$ \\
\hline
\end{tabular}

Lag length of ADF test is taken based on general to specific method setting maximum number of lag as 20. For PP test the lag is taken based on Newey West method. 
${ }^{\mathrm{a}, \mathrm{b}}$ and ${ }^{\mathrm{c}}$ imply significance at $1 \%, 5 \%$ and $10 \%$ significance level, respectively.

Table 3. Result of Unit Root Test for weekly return

\begin{tabular}{|c|c|c|c|c|c|c|}
\hline & \multicolumn{2}{|c|}{$\mathrm{ADF}$} & \multicolumn{2}{|r|}{ PP } & \multicolumn{2}{|c|}{ KPSS } \\
\hline CURRENCIES & Drift & Trend & Drift & Trend & Drift & Trend \\
\hline GBP & $-7.1316^{\mathrm{a}}$ & $-7.2603^{\mathrm{a}}$ & $-29.5937^{\mathrm{a}}$ & $-29.6994^{\mathrm{a}}$ & $0.393^{\mathrm{c}}$ & 0.037 \\
\hline USD & $-8.1270^{\mathrm{a}}$ & $-9.9472^{\mathrm{a}}$ & $-28.3003^{a}$ & $-28.4339^{a}$ & $0.659^{\mathrm{b}}$ & 0.089 \\
\hline $\mathrm{CHF}$ & $-30.7089^{a}$ & $-30.7402^{a}$ & $-30.7388^{a}$ & $-30.7868^{a}$ & 0.230 & 0.082 \\
\hline AUD & $-31.9318^{\mathrm{a}}$ & $-31.9179^{a}$ & $-31.9783^{\mathrm{a}}$ & $-31.9804^{\mathrm{a}}$ & 0.079 & 0.054 \\
\hline NZD & $-7.4723^{a}$ & $-7.5109^{\mathrm{a}}$ & $-31.6277^{\mathrm{a}}$ & $-31.6529^{a}$ & 0.175 & 0.075 \\
\hline JPY & $-8.0455^{\mathrm{a}}$ & $-7.3868^{\mathrm{a}}$ & $-31.6553^{a}$ & $-31.7106^{\mathrm{a}}$ & 0.329 & $0.138^{\mathrm{c}}$ \\
\hline SGD & $-10.3891^{\mathrm{a}}$ & $-10.4786^{\mathrm{a}}$ & $-31.4632^{\mathrm{a}}$ & $-31.5797^{\mathrm{a}}$ & $0.611^{\mathrm{b}}$ & $0.219^{\mathrm{b}}$ \\
\hline HKD & $-9.6701^{a}$ & $-9.8608^{\mathrm{a}}$ & $-28.2099^{a}$ & $-28.3458^{a}$ & $0.650^{\mathrm{b}}$ & 0.089 \\
\hline
\end{tabular}

Lag length of ADF test is taken based on general to specific method setting maximum number of lag as 20. For PP test the lag is taken based on Newey West method. ${ }^{\mathrm{a},} \quad{ }^{\mathrm{b}}$ and ${ }^{\mathrm{c}}$ imply significance at $1 \%, 5 \%$ and $10 \%$ level, respectively.

Table 4. Result of Lo-MacKinlay and Chow Denning Variance Ratio for weekly return

\begin{tabular}{|c|c|c|c|c|c|}
\hline & \multicolumn{4}{|c|}{ Lo-MacKinlay Variance Ratio Statistics } & \multirow[t]{2}{*}{ Chow Denning } \\
\hline Currencies & 2 & 4 & 8 & 16 & \\
\hline GBP-VR (k) & 1.059 & 1.027 & 0.993 & 0.9146 & \\
\hline $\mathrm{M}_{1}(\mathrm{k})$ & $1.848^{\mathrm{c}}$ & 0.446 & -0.076 & -0.610 & 1.848 \\
\hline $\mathrm{M}_{2}(\mathrm{k})$ & 1.043 & 0.275 & -0.052 & -0.464 & 1.043 \\
\hline USD-VR(k) & 1.105 & 1.030 & 1.051 & 1.028 & \\
\hline $\mathrm{M}_{1}(\mathrm{k})$ & $3.302^{\mathrm{a}}$ & 0.497 & 0.541 & 0.199 & $3.302^{\mathrm{a}}$ \\
\hline $\mathrm{M}_{2}(\mathrm{k})$ & 0.840 & 0.153 & 0.210 & 0.984 & 0.840 \\
\hline CHF-VR (k) & 1.022 & 0.987 & 0.944 & 0.876 & \\
\hline $\mathrm{M}_{1}(\mathrm{k})$ & 0.702 & -0.223 & -0.593 & -0.887 & 0.887 \\
\hline $\mathrm{M}_{2}(\mathrm{k})$ & 0.509 & -0.176 & -0.511 & -0.808 & 0.808 \\
\hline AUD-VR (k) & 0.980 & 0.919 & 0.910 & 0.822 & \\
\hline $\mathrm{M}_{1}(\mathrm{k})$ & -0.632 & -1.366 & -0.954 & -1.271 & 1.367 \\
\hline $\mathrm{M}_{2}(\mathrm{k})$ & -0.310 & -0.744 & -0.612 & -0.940 & 0.940 \\
\hline NZD-VR (k) & 0.991 & 0.958 & 0.909 & 0.842 & \\
\hline $\mathrm{M}_{1}(\mathrm{k})$ & -0.284 & -0.706 & -0.969 & -1.128 & 1.129 \\
\hline $\mathrm{M}_{2}(\mathrm{k})$ & -0.190 & -0.511 & -0.769 & -0.952 & 0.952 \\
\hline JPY-VR (k) & 0.993 & 0.982 & 0.906 & 1.038 & \\
\hline $\mathrm{M}_{1}(\mathrm{k})$ & -0.237 & -0.302 & -0.307 & 0.274 & 0.357 \\
\hline $\mathrm{M}_{2}(\mathrm{k})$ & -0.147 & -0.203 & -0.257 & 0.213 & 0.257 \\
\hline SGD-VR (k) & 1.003 & 0.895 & 0.845 & 0.784 & \\
\hline $\mathrm{M}_{1}(\mathrm{k})$ & 0.089 & $-1.766^{c}$ & $-1.646^{c}$ & -1.546 & 1.766 \\
\hline $\mathrm{M}_{2}(\mathrm{k})$ & 0.027 & -0.634 & -0.738 & -0.866 & 0.866 \\
\hline HKD-VR (k) & 1.107 & 1.044 & 1.073 & 1.061 & \\
\hline $\mathrm{M}_{1}(\mathrm{k})$ & $3.387^{\mathrm{a}}$ & 0.744 & 0.779 & 0.440 & $3.387^{\mathrm{a}}$ \\
\hline $\mathrm{M}_{2}(\mathrm{k})$ & 0.881 & 0.233 & 0.308 & 0.220 & 0.881 \\
\hline
\end{tabular}

The $\operatorname{VR}(q)$ are reported in the first row and test statistic $\mathrm{M}_{1}(\mathrm{k})$ for homoskedastic increments and $\mathrm{M}_{2}(\mathrm{k})$, heteroscedastic robust test statistic are given in second and third row.$^{\mathrm{a}, \mathrm{b}}$ and ${ }^{\mathrm{c}}$ are significant at $1 \%, 5 \%$ and $10 \%$ significance level, respectively. 
Table 5. p-value of Bootstrapped Lo-MacKinlay and Chow Denning Variance Ratio test statistics

\begin{tabular}{|c|c|c|c|c|c|}
\hline${ }_{\text {currencies }}^{\mathrm{k}}$ & $\mathrm{k}=2$ & $\mathrm{k}=4$ & $\mathrm{k}=8$ & $\mathrm{k}=16$ & Chow Denning \\
\hline GBP & 0.216 & 0.188 & 0.227 & 0.472 & 0.364 \\
\hline USD & 0.191 & $0.070^{\mathrm{c}}$ & $0.061^{\mathrm{c}}$ & $0.094^{\mathrm{c}}$ & 0.124 \\
\hline $\mathrm{CHF}$ & 0.507 & 0.460 & 0.583 & 0.837 & 0.745 \\
\hline AUD & 0.947 & 0.944 & 0.820 & 0.936 & 0.989 \\
\hline NZD & 0.961 & 0.795 & 0.975 & 0.768 & 0.986 \\
\hline JPY & 0.941 & 0.514 & 0.579 & 0.311 & 0.584 \\
\hline SGD & 0.787 & 0.575 & 0.507 & 0.526 & 0.767 \\
\hline HKD & 0.184 & $0.058^{\mathrm{c}}$ & $0.051^{\mathrm{c}}$ & 0.700 & $0.093^{\mathrm{c}}$ \\
\hline
\end{tabular}

c is significant at $10 \%$ level.

Table 6. Result of Wright's Ranks and Sign Test for weekly return

\begin{tabular}{|c|c|c|c|c|c|c|}
\hline Currencies & Lags & $k=2$ & $k=4$ & $k=8$ & $k=16$ & Joint Wright \\
\hline \multirow{3}{*}{ GBP } & $\mathrm{R} 1$ & 0.995 & 0.517 & -0.159 & -0.787 & 0.995 \\
\hline & $\mathrm{R} 2$ & 1.18 & 0.633 & 0.014 & -0.644 & 1.180 \\
\hline & $\mathrm{S} 1$ & -0.286 & 0.187 & 0.274 & 0.181 & 0.286 \\
\hline \multirow{3}{*}{ USD } & $\mathrm{R} 1$ & 0.143 & $1.726^{\mathrm{C}}$ & 0.861 & $4.608^{\mathrm{a}}$ & $4.608^{a}$ \\
\hline & $\mathrm{R} 2$ & 0.667 & $1.824^{\mathrm{c}}$ & $2.689^{a}$ & $3.725^{\mathrm{a}}$ & $3.725^{\mathrm{a}}$ \\
\hline & $\mathrm{S} 1$ & -0.731 & 0.833 & $2.628^{\mathrm{b}}$ & $4.92^{\mathrm{a}}$ & $4.920^{\mathrm{a}}$ \\
\hline \multirow{3}{*}{$\mathrm{CHF}$} & $\mathrm{R} 1$ & 0.424 & 0.485 & 0.287 & 0.237 & 0.485 \\
\hline & $\mathrm{R} 2$ & 0.288 & 0.071 & -0.147 & -0.369 & 0.369 \\
\hline & $\mathrm{S} 1$ & -0.541 & -0.578 & -0.22 & 0.166 & 0.578 \\
\hline \multirow{3}{*}{ AUD } & $\mathrm{R} 1$ & -0.517 & -0.139 & -0.405 & -0.402 & 0.517 \\
\hline & $\mathrm{R} 2$ & -0.619 & -0.492 & -0.152 & -0.539 & 0.619 \\
\hline & $\mathrm{S} 1$ & 0.35 & 1.02 & 1.526 & $2.003^{\mathrm{b}}$ & $2.003^{b}$ \\
\hline \multirow{3}{*}{ NZD } & $\mathrm{R} 1$ & -0.019 & -0.247 & -0.402 & -0.264 & 0.402 \\
\hline & $\mathrm{R} 2$ & -0.324 & -0.518 & -0.722 & -0.773 & 0.773 \\
\hline & $\mathrm{S} 1$ & 0.095 & 0.136 & 0.215 & 0.961 & 0.961 \\
\hline \multirow{3}{*}{ JPY } & $\mathrm{R} 1$ & -0.338 & 0.284 & -0.28 & 0.129 & 0.338 \\
\hline & $\mathrm{R} 2$ & -0.863 & -0.24 & -0.588 & -0.106 & 0.863 \\
\hline & $\mathrm{S} 1$ & 0.795 & 1.445 & 0.591 & 0.419 & 1.445 \\
\hline \multirow{3}{*}{ SGD } & $\mathrm{R} 1$ & 0.683 & $1.653^{\mathrm{c}}$ & $1.705^{\mathrm{c}}$ & $1.789^{\mathrm{c}}$ & $1.789^{\mathrm{c}}$ \\
\hline & $\mathrm{R} 2$ & 0.078 & $0.901^{\mathrm{c}}$ & 0.917 & 0.864 & 0.917 \\
\hline & $\mathrm{S} 1$ & 0.095 & 1.258 & $2.085^{\mathrm{b}}$ & $2.559^{\mathrm{b}}$ & $2.559^{\mathrm{b}}$ \\
\hline \multirow{3}{*}{ HKD } & $\mathrm{R} 1$ & 0.503 & $1.707^{\mathrm{c}}$ & $2.511^{\mathrm{b}}$ & $4.022^{\mathrm{a}}$ & $4.022^{\mathrm{a}}$ \\
\hline & $\mathrm{R} 2$ & 0.969 & $1.926^{\mathrm{b}}$ & $2.553^{\mathrm{b}}$ & $3.453^{\mathrm{a}}$ & $3.453^{\mathrm{a}}$ \\
\hline & S1 & -0.223 & 0.459 & 1.403 & $3.267^{\mathrm{a}}$ & $3.267^{\mathrm{a}}$ \\
\hline
\end{tabular}

${ }^{\mathrm{a}, \mathrm{b}}$ and ${ }^{\mathrm{c}}$ are significant at $1 \%, 5 \%$ and $10 \%$ significance level , respectively.

Table 7. Runs Test for weekly return

\begin{tabular}{|l|l|l|l|l|}
\hline Currencies & No. of runs & $\mathrm{N}<=$ Mean & $\mathrm{N}>$ Mean & Z statistics \\
\hline GBP & 499 & 484 & 504 & $0.24(0.81)$ \\
\hline USD & 406 & 629 & 360 & $-3.64^{\mathrm{a}}(0.00)$ \\
\hline CHF & 495 & 511 & 478 & $0.000(1.00)$ \\
\hline AUD & 487 & 582 & 507 & $-0.52(0.60)$ \\
\hline NZD & 503 & 479 & 510 & $0.51(0.61)$ \\
\hline JPY & 488 & 525 & 464 & $-0.36(0.72)$ \\
\hline SGD & 477 & 523 & 466 & $-1.08(0.28)$ \\
\hline HKD & 418 & 625 & 364 & $-2.95^{\mathrm{a}}(0.00)$ \\
\hline
\end{tabular}

${ }^{\mathrm{a}}$ indicate significance at $1 \%$ significance level. Figures in parentheses are p-values of $\mathrm{z}$-statistics. 